\title{
Mobile learning in the teaching of mathematics: a conceptual cartography
}

\section{El aprendizaje móvil en la enseñanza de las matemáticas: una cartografía conceptual}

\author{
URIBE-HERNÁNDEZ, Mayra†*, LARIOS-OSORIO, Víctor and ESCUDERO-NAHÓN, Alexandro \\ Universidad Autónoma de Querétaro, Faculty of Informatics, Mexico.
}

ID $1^{\text {st }}$ Author: Mayra, Uribe-Hernández / ORC ID: 0000-0002-8416-9721, CVU CONACYT ID: 489839

ID $1^{\text {st }}$ Coauthor: Víctor, Larios-Osorio / ORC ID: 0000-0002-4454-8516

ID $2^{\text {nd }}$ Coauthor: Alexandro, Escudero-Nahón / ORC ID: 0000-0001-8245-0838

DOI: 10.35429/JCT.2020.12.4.1.11

Received: January 10, 2020; Accepted June 30, 2020

\begin{abstract}
Designing a mobile learning environment for mathematics education requires an understanding of how technology relates to various epistemological and pedagogical systems. The purpose of this study was to systematically analyze scientific literature on mobile learning in mathematics teaching through the axes of conceptual mapping within the framework of qualitative research. The analysis categories were: notion, categorization, characterization, differentiation, methodology and exemplification. The contribution of this work refers to the definition of mobile learning in the teaching of mathematics considering its characteristics, such as context creation, social interaction, multimedia content and usability. It was identified that mobile learning increases the possibilities of electronic learning and enables ubiquitous learning when the student is immersed in the learning context. The studies analyzed do not report a precise methodology that allows evaluating the relevance of the design of a mobile learning environment. However, it was identified that the choice of the pedagogical principles and the definition of a thematic axis are fundamental. In addition to the demand for teachers' theoretical, pedagogical and digital skills. This work provides elements that could guide further research and applications.
\end{abstract}

Mobile learning, Mobile devices, Mathematics education

\section{Resumen}

El diseño de un entorno de aprendizaje móvil en la enseñanza de las matemáticas requiere que se comprenda cómo se relaciona la tecnología con los diversos sistemas epistemológicos y pedagógicos. El presente estudio tuvo el propósito de analizar sistemáticamente literatura científica sobre el aprendizaje móvil en la enseñanza de las matemáticas mediante los ejes de la cartografía conceptual dentro del marco de la investigación cualitativa. Las categorías de análisis fueron: noción, categorización, caracterización, diferenciación, metodología y ejemplificación. El aporte del presente trabajo refiere a la definición del aprendizaje móvil en la enseñanza de las matemáticas considerando sus características, como creación de contextos, interacción social, contenido multimedia y usabilidad. Se identificó que el aprendizaje móvil incrementa las posibilidades del aprendizaje electrónico y posibilita el aprendizaje ubicuo cuando el estudiante está inmerso en el contexto de aprendizaje. Los estudios analizados no reportan una metodología precisa que permita evaluar la pertinencia del diseño de un entorno de aprendizaje móvil. Sin embargo, se identificó que la elección de principios pedagógicos y la definición de un eje temático son fundamentales. Además de la demanda de habilidades teóricas, pedagógicas y digitales de los docentes. Este trabajo proporciona elementos que podrían orientar nuevas investigaciones y aplicaciones.

Aprendizaje móvil, Dispositivos móviles, Educación matemática

Citation: URIBE-HERNÁNDEZ, Mayra, LARIOS-OSORIO, Víctor and ESCUDERO-NAHÓN, Alexandro. Mobile learning in the teaching of mathematics: a conceptual cartography. Journal Computer Technology. 2020. 4-12:1-11.

\footnotetext{
* Correspondence to the author (Email: muribe37@alumnos.uaq.mx).

$\dagger$ Researcher contributing as first author.
} 


\section{Introduction}

The relevant teaching and learning of mathematics involves the development of activities to achieve specific educational objectives. These activities are conditioned by the environment and the use of technological means (Godino, 2013). For the incorporation of technology in the educational field of a disciplinary field such as mathematics, the work that the software manages on school knowledge and its association with the epistemological environment must be considered, as well as the optimal design of the interface to transmit the elements symbolic characteristics of mathematical language (Camacho Ríos, Caldera Franco, \& Valenzuela González, 2019).

The use of personal electronic devices in the teaching of mathematics has made it possible to access multimedia content, the creation of diverse learning contexts and diverse means of communication between teacher and student, fundamental components in a mobile learning environment.

The design of this learning environment demands the understanding of how technology is related to the epistemological and pedagogical systems that underpin the learning and teaching process of a disciplinary field (Bano, Zowghi, Kearney, Schuck, \& Aubusson, 2018) which evidences the relevance of the implemented didactic rules

The teaching of mathematics presents the challenge of developing skills in the student that allow them to solve problems of daily life through mathematical models (Aragón, Castro, Gómez, \& González, 2009), the difficulty in this disciplinary field is due to the characteristic abstract and intrinsic that mathematical meanings possess (Duval, 2006). Therefore, the relevance of analyzing in depth the incorporation of technology in the teaching of mathematics.

The present study had the purpose of systematically analyzing scientific literature on mobile learning in mathematics teaching through the axes of conceptual mapping within the framework of qualitative research.

\section{Methodology}

For the development of this work, a documentary analysis was carried out around the concept of "mobile learning in the teaching of mathematics", within the framework of qualitative research. The stages that refer to the documentary research process were followed. These are search, selection, analysis and interpretation of secondary data, that is, those obtained and recorded by researchers in documentary sources, with the purpose of providing new knowledge.

For the analysis stage, the axes proposed by conceptual cartography were considered, which is defined as a strategy to systematize, build, communicate and learn academic concepts, considering previous knowledge and theoretical references around an area of interest, following 8 axes (Hernández-Mosqueda, TobónTobón, \& Vázquez-Antonio, 2014):

- Notion: Describes the etymology of the concept, its historical development and the current definition with its different meanings.

- Categorization: Refers to the definition and characteristics of the immediate class and subsequent class, considering the concept in a general class as part of a whole.

- Characterization: Describes the key features of the concept taking into account the notion and categorization.

- Differentiation: Identifies similar concepts, they are defined and they differ from the analyzed concept.

- Classification: Determines in which subclasses or types the study concept is classified.

- Linkage: Links the concept with theories, social-cultural processes and epistemological references that are outside the identified categorization, which provide contributions to the understanding, construction and application of the concept.

- Methodology: Describes the key elements of the methodology to apply the concept in situations and problems of the context. 
- Exemplification: Describes an example of how the concept is applied in activities or problems in the social, work or professional context.

In this work, the axes proposed by Tobón (2017) were considered with the exception of classification and linkage, since the studies analyzed did not yield enough information to identify subclasses of these concepts. Due to the fact that "mobile learning" arises in the educational field, the studies did not provide data on disciplinary processes outside this field that were related to the study concept. The information referred to in each axis was systematically analyzed in order to evaluate the reported results, define possible gaps and communicate data for future studies.

\section{Document selection criteria}

Considering the axes of the conceptual cartography, research articles referring to mobile learning in mathematics teaching were searched. The period of the publications was established between 2010 and 2019, considering that the first studies on mobile learning date from 2010 (Borba et al., 2016). Studies referring to mobile learning for the teaching of thematic axes other than the area of mathematics were excluded.

\section{Study categories}

Table 1 describes the six axes considered in the conceptual mapping, through which the information gathered from the research articles selected for analysis was organized.

\begin{tabular}{|c|c|}
\hline Analysis axis & Core ítems \\
\hline $\begin{array}{l}\text { Notion } \\
\text { What is mobile learning in } \\
\text { the teaching of mathematics? }\end{array}$ & $\begin{array}{l}\text { Current definition. } \\
\text { Historical development } \\
\text { of mobile learning. }\end{array}$ \\
\hline $\begin{array}{l}\text { Categorization To which } \\
\text { category does the mobile } \\
\text { learning concept belong in } \\
\text { the teaching of mathematics? }\end{array}$ & $\begin{array}{lr}\text { Immediate } & \text { class: } \\
\text { definition } & \text { and } \\
\text { characteristics. } & \end{array}$ \\
\hline $\begin{array}{l}\text { Characterization What are } \\
\text { the elements that give } \\
\text { identity to mobile learning in } \\
\text { the teaching of mathematics? }\end{array}$ & $\begin{array}{l}\text { Key characteristics } \\
\text { considering the notion } \\
\text { and categorization. }\end{array}$ \\
\hline $\begin{array}{l}\text { Differentiation From what } \\
\text { other similar concepts does } \\
\text { mobile learning differ in the } \\
\text { teaching of mathematics? }\end{array}$ & $\begin{array}{l}\text { Similar concepts are } \\
\text { described, defined, and } \\
\text { differentiated. }\end{array}$ \\
\hline $\begin{array}{l}\text { Methodology What are the } \\
\text { essential axes for the } \\
\text { implementation of a mobile } \\
\text { learning environment in the } \\
\text { teaching of mathematics? }\end{array}$ & $\begin{array}{l}\text { The essential axes for } \\
\text { the implementation of } \\
\text { the approach are } \\
\text { described. }\end{array}$ \\
\hline
\end{tabular}

\begin{tabular}{|c|c|}
\hline $\begin{array}{l}\text { Exemplification What could } \\
\text { be a relevant example of a } \\
\text { mobile learning environment } \\
\text { in teaching mathematics? }\end{array}$ & $\begin{array}{l}\text { Describe a concrete } \\
\text { example that illustrates } \\
\text { the application of the } \\
\text { methodology with } \\
\text { details of the context. }\end{array}$ \\
\hline
\end{tabular}

Table 1 Axes of the conceptual mapping on mobile learning in mathematics teaching

\section{Phases of the study}

Figure 1 illustrates the stages of the present work. The first phase of the conceptual study was carried out by searching for research articles considering two main fields: mathematics education and mobile learning. Search terms (math * education AND "mobile learning") were used in three electronic databases: ScienceDirect, Web of Science and Springer Link. In the case of the Springer Link database, Education was selected as the specific discipline.

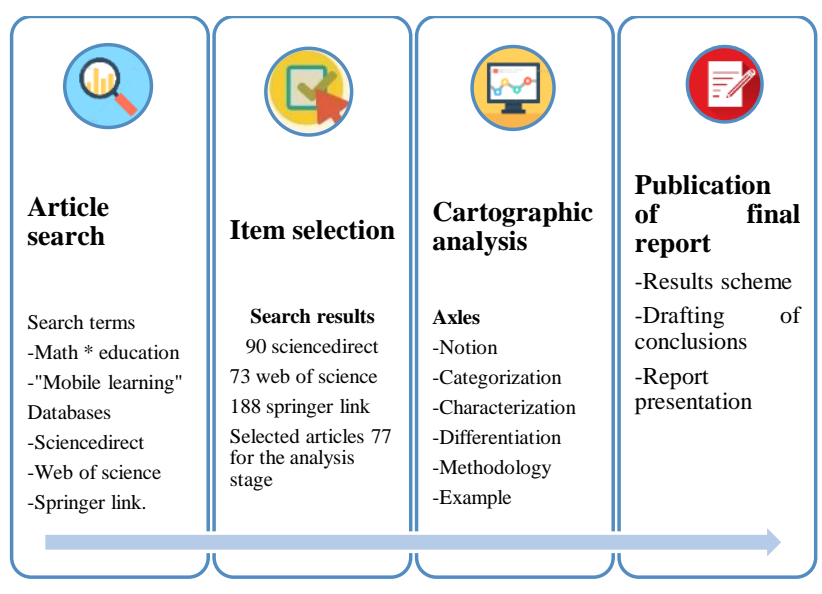

Figure 1 Phases of documentary research

The second phase consisted of the selection of research articles relevant to the study concept. We found 90 articles from ScienceDirect, 73 from Web of Science and 188 from Springer Link, giving a total of 351 articles. For the present work, 77 articles were analyzed, which were considered relevant in relation to the axes of analysis of the conceptual cartography.

The third phase was carried out through cartographic analysis. After the selection of the research articles, the conceptual cartography was elaborated considering the six axes proposed in Table 1. 
The fourth phase refers to the publication of the results, through the presentation of a report and the writing of the conclusions, identifying the contribution of the present work for future research on the relationships between the technology of a mobile learning environment and the pedagogical components in the teaching of mathematical knowledge.

\section{Results}

This section reports the results that refer to the analysis of the axes proposed in the conceptual mapping, which are illustrated in Figure 2 in a general way.

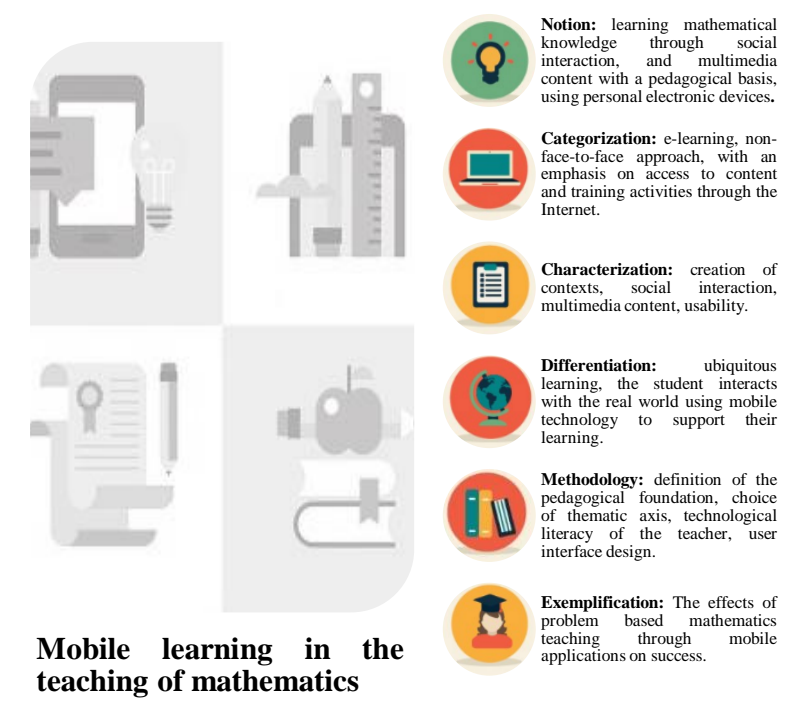

Figure 2 Diagram of the results of the analysis based on the axes of the conceptual mapping

\section{Notion of mobile learning in the teaching of mathematics}

The concept of "mobile learning" emerged as an extension of distance education and distributed technology, through the use of mobile devices and wireless networks (Liu \& Zhang, 2017). This approach links individualized learning with learning at any time and in any place, it focuses on the student's experience, providing a diversity of multimedia content through touch screens (Skiada, Soroniati, Gardeli, \& Zissis, 2014).

Various authors (Borba et al., 2016; Bray \& Tangney, 2015; Roberts, 2014) refer to the definition proposed by Crompton (2013, p. 4): "learning in multiple contexts, through social and content interactions, using personal electronic devices".
Therefore, learning must be significant as a factor of formal or informal education (Fessakis, Karta, \& Kozas, 2018), due to the properties of mobile devices, the dependence on fixed locations decreases (Juhan \& Halkias, 2017). that allows the creation of new learning contexts (Joo Nagata, García-Bermejo Giner, \& Martínez Abad, 2017; Schuck, 2016) that are enriched thanks to the characteristics of multimedia content, giving a new dimension to the school curriculum in the formal educational context (Handal, Campbell, Cavanagh, \& Petocz, 2016), learning can occur in an informal context when the opportunities offered by mobile technology are taken advantage of (Ludwig \& Jesberg, 2015; Rodríguez, Spiegel, Salviolo, \& Peña, 2015).

The notion of mobile learning has components that have been analyzed in research studies for the teaching of mathematics, which refer to context, social interaction and content. The possibility that learning occurs in various contexts is relevant to the fact that when mathematics is taught, "classroom practice can be seen as a system of adaptation of the student to society" (D'Amore, Radford, \& Bagni, 2006, p. 27), doing mathematics refers to a human activity, which is developed in a context, uses various instruments and provides techniques for the achievement of specific tasks (Chevallard, 1992).

The approach and resolution of mathematical problems encourages communication, discussion and validation of solutions, so that social interaction acquires relevance in the construction of knowledge. The dialogue between teacher-student allows to identify the acquisition of erroneous meanings, false conclusions and the timely resolution of doubts (Alsina \& Domingo, 2010).

Mobile learning allows the interaction of multimedia content, which for mathematical work refers to concepts such as procedures, algorithms, propositions, demonstrations, problems or language. For the teaching of mathematics, the theoretical content and the way in which it is transmitted and how the student acquires it is relevant (Radford, 2004). 


\section{Categorization of mobile learning in the teaching of mathematics}

The use of mobile technology in education considers electronic learning (e-learning) through mobile devices to create a ubiquitous educational experience (Nicolete, Bilessimo, Cristiano, Simão, \& da Silva, 2017). Electronic learning is a non-face-to-face approach, with an emphasis on access to content and training activities through the Internet, which promotes interaction and communication among participants. It is aimed at the acquisition of skills in a social context through a technological ecosystem, in which the teaching actors contribute to guaranteeing the quality of the various factors involved, mainly the pedagogical design.

A fundamental characteristic of electronic learning is the student's capacity for self-regulation in her learning process, since she must define objectives and strategies considering attributes such as personalization, interaction, authenticity, scaffolding and reflection. In this approach, the autonomy of the student is a crucial factor for the achievement of goals (Salvat, 2018), since in the process of teaching mathematics the subjects dialogue and regulate the expressions and actions before certain mathematical problems, systems of shared practices within a specific context, but subjective knowledge also arises in relation to the student's thoughts and actions (Godino, 2003).

\section{Characteristics of mobile learning in the teaching of mathematics}

The understanding of "the nature of the mathematical concepts and propositions themselves and their dependence on the contexts and situations-problems from whose resolution they come" (Godino, 2003, p. 22) is fundamental in the learning process, which shows the relevance of the characteristics that identify mobile learning in the teaching of mathematical knowledge.
- Creation of contexts. Portability, the integration of a Global Positioning System (GPS) and access to the Internet of mobile devices have allowed their integration in the educational field to generate personalized, connected and collaborative learning environments. The creation of contexts is a relevant feature of mobile learning in the teaching of mathematics, it allows exploring the learning process through everyday situations or contextual problems to form formal relationships and abstract structures. The relevance in mathematics teaching is related to the degree of adequacy of the study process in the conditions of the student's environment inside and outside the school classroom.

- Social interaction. For mobile learning, social interaction refers to communication between the various agents involved in a learning environment; In the teaching of mathematics, argumentation, agreements, the identification of erroneous concepts and dialogue are fundamental in collaborative environments and their practice is promoted in the school classroom.

Multimedia content. It refers to that which uses several means simultaneously in the transmission of information. Multimedia content, therefore, can include photos, videos, sounds, and text. It makes possible the diversity in the contents, the didactic activities and the evaluation methods; creates new forms of interaction and communication between the agents involved; these media interact with mathematical problems, representations, definitions, propositions and arguments. The relevance of the learning process is related to the availability of material resources and their adequacy with the intended meanings. 
Usability In mobile learning, the interaction between subjects and shared content occurs through the interface of mobile devices, this process is inherent to the user experience, which describes the need to design an efficient environment for the correct reading of the information, which implies that distractions are avoided in a learning environment; In the teaching of mathematics, the theoretical content and the method to transmit it must be considered, so the usability characteristic refers to the design of didactic activities through the collaboration of expert teachers in the disciplinary field and experienced developers.

\section{Differentiation of mobile learning and ubiquitous learning in mathematics teaching}

Mobile learning enables the interaction of the various agents of a learning process through various contexts and everyday situations, this due to the inherent characteristics of mobile devices that allow communication at any time and place. This ubiquity encourages the creation of learning environments adapted to the social and educational context that students experience. These possibilities of access and interaction between the subjects and the contents have led to the design of learning environments that consider contexts in which the participants are immersed, it is this deliberate adaptation of the teaching proposal with the context that differentiates ubiquitous learning of mobile learning. Therefore, in a ubiquitous learning environment, the student is totally immersed in the learning process and could even learn without being fully aware of the process (Zhao, Wan, \& Okamoto, 2010).

Ubiquitous learning creates a didactic experience "in which the student is interacting with a real world environment while using mobile technology to support their learning" (Borba et al., 2016, p. 20), so the relevance of the Ubiquitous learning largely depends on the surrounding context of the students.

Ubiquitous learning is based on the principles of adaptive learning, the potential of ubiquitous computing and the flexibility of mobile devices; focuses on the individual needs and learning styles of the student for the relevant design of educational settings (Joung-Souk, 2009).
To facilitate the learning process, the monitoring of the activity, the interpretation of results, the analysis of requirements and student preferences are considered.

Ubiquitous learning has potential for the teaching of mathematics considering that the appropriation of mathematical knowledge is attributed to its relationship with the cultural reality of students (Godino, 2003).

\section{Methodology to evaluate the efficiency of a mobile learning environment in the teaching of mathematics}

The studies were not conclusive regarding the methodology for evaluating a learning environment focused on the teaching of mathematics, in which social interactions and multimedia content occur through mobile devices. However, it was possible to identify methodological components considering the teaching of mathematical knowledge as an objective. These components are:

- Definition of the pedagogical foundation. The Didactics of Mathematics in the field of research studies the factors that condition the process of teaching and learning mathematics, and the development of programs to improve these processes. For the design of a mobile learning environment in the teaching of this disciplinary field, it will be essential to start with the definition of the pedagogical approach to the use of technology, to guarantee that the implemented didactic standards are based on a theoretical framework, the result of research and analysis of the nature of mathematical knowledge.

- Choice of thematic axis. The choice of a thematic axis should consider the analysis of the mathematical contents to be problematized, as well as their cultural and personal development in the didactic systems. This process will allow the definition of feasible learning objectives and the pertinent evaluation of the learning process, that is, to evaluate whether the knowledge transmitted corresponds to the knowledge acquired. 
- Technological literacy of the teacher. In a mobile learning environment, usually in formal educational contexts, the technological literacy of the teacher acquires relevance and is fundamental for the design of educational environments with pedagogical considerations. A deep reflection on the meaning of mathematical content and knowledge about the use of technological tools that allow modifying, enriching and diversifying their academic work through resources from their daily context is required from the mathematics teacher. Digital skills must be defined in relation to the curriculum of each educational level, in addition to considering the academic discipline as a fundamental axis in a technological development project (Ramírez Martinell, Casillas Alvarado, \& Aguirre González, 2018).

- User interface design. The challenge in teaching mathematics is to achieve in the student the development of thinking skills and the use of tools to solve problems in their daily context through mathematical models (Aragón et al., 2009), a mobile learning environment in the The teaching of mathematics should consider that access to content through mobile devices requires the effective design and development of user interfaces, considering the characteristics of the resources that will be used to convey mathematical meanings. An efficient interface design will facilitate the interaction between the subjects of the environment and the multimedia content, which is why the collaborative work of teachers and designers is essential.

\section{Exemplification of the methodological components of a mobile learning environment for the teaching of mathematical knowledge}

This section analyzes the study the effects of problem based mathematics teaching through mobile applications on success (Çetinkaya, 2019). The purpose of the research was to determine the effects of problem-based math teaching through mobile applications as assistive technology.
The following research questions were posed:

1. Is there a significant difference between the success scores of students who are taught with the problem-based app with mobile assistance and the success scores of students who are educated in the traditional setting?

2. What are the opinions of the students about the effectiveness of the study process?

Research model. The explanatory design of the mixed method was used; For the quantitative dimension, the quasiexperimental design was used with a pretest-posttest control group.

- Study group. The quantitative dimension of the study refers to a total of 62 students (16 girls and 15 boys in the experimental group, and 17 girls and 14 boys in the control group). The participants had smartphones, internet access and the WhatsApp application. Information was provided on the mobile applications that were used in the process, considering technical requirements.

Implementation phase. Figure 3 illustrates the components described in the study during this stage. It begins by defining the didactic design in relation to the content of the subject area; The terms and concepts of: data, discrete data, continuous data, arithmetic mean, median, mode, interval, maximum value, minimum value, lower quartile, upper quartile, interquartile range, standard deviation, line graph, bar graph are covered, pie chart, histogram, group count, group width.
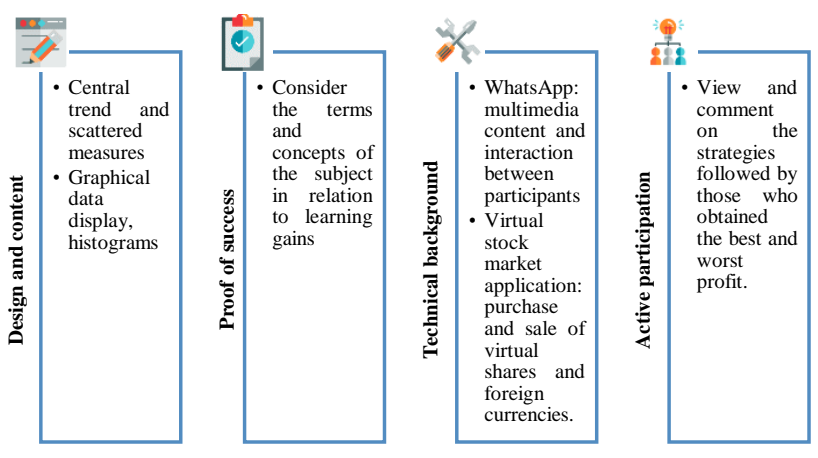

Figure 3 Detail of the components considered in the implementation phase of the study 
A success test was designed, which consisted of a series of questions to determine the level of understanding of the students considering the terms and concepts included in the subject.

Technical aspects were defined in relation to the selected technology, the WhatsApp application was used for the interaction and support of multimedia content. A virtual stock market application was used for the students to graphically monitor the buying and selling of foreign stocks and currencies, using data from the Istanbul stock exchange.

All participants were able to see and comment on the strategies followed by those who made the best and worst profit, increasing their active participation.

Data collection. Quantitative study data was collected using the 80-item success test for evaluations.

Qualitative data were collected using an open questionnaire.

Data analysis. A two-factor analysis of variance was performed for the mixed measures, since the distribution fulfilled the assumption of normality and there were two groups. For the open questions, which refers to the qualitative dimension of the study, the data of the students of the experimental group were analyzed using categorical and frequency analysis techniques.

Study results. Problem-based learning supported by mobile technology is effective in increasing students' understanding. The students emphasized elements such as learning anytime anywhere, sharing resources and materials, organizing activities for academic purposes. According to the findings, the use of mobile technology provided technical, educational and academic advantages. A natural environment of competition was formed during the process thanks to the interaction of the students with real life and with each other.

\section{Conclusions}

The results of this study define the notion of mobile learning in the teaching of mathematics as the learning of mathematical knowledge in different contexts of the real world, through social interaction between students and teachers, and multimedia content with pedagogical basis in the disciplinary field, using personal electronic devices.

The notion of mobile learning in the teaching of mathematics has components that refer to the creation of contexts, social interaction, multimedia content and usability. Considering that doing mathematics refers to a human activity, a mobile learning environment allows the development of contexts associated with daily life, thereby promoting the use of multiple tools and techniques to achieve mathematical learning; Communication in these contexts allows dialogue between studentteacher, this social interaction facilitates the timely resolution of doubts, allows identifying the acquisition of erroneous meanings and promotes argumentation, fundamental elements in the teaching of mathematics. The multimedia content presents possibilities that for the teaching of mathematics have an implication in the theoretical knowledge that is transmitted, the way in which it is transmitted and how the student acquires the meanings; This implies that the design of the didactic activities impacts usability, which describes the need for an efficient design of the interface, which will be the medium where the participants and the content interact.

The use of mobile technology in the educational field boosted the possibilities of electronic learning, by creating a ubiquitous educational experience, so that access to content and interaction among participants presented new possibilities in the teaching of mathematics. This ubiquity has allowed the design of learning environments that consider contexts in which the participants are immersed, this characteristic makes the difference between ubiquitous learning and mobile learning. 
Although the studies were not conclusive on the definition of a methodology for the design of a mobile learning environment focused on the teaching of mathematics, methodological components were identified that refer to the definition of the pedagogical foundation, the choice of the thematic axis, literacy teacher technology and user interface design.

The relevance of the definition of the pedagogical approach to the use of technology has the objective of guaranteeing that the didactic strategies implemented are based on the results of the research. In the teaching of mathematics, the choice of a thematic axis facilitates the definition of viable learning objectives, so the analysis of mathematical content and its relationship with the cultural and personal context of the didactic systems should be considered.

By incorporating technology, the teacher is required not only to have a deep knowledge of the mathematical meanings that she will teach, but also about the use of technological tools that diversify her academic work, with which digital literacy is a crucial factor for the relevant designTo convey the mathematical meanings in a pertinent way, the design and effective development of user interfaces should be considered, since this will be the means to visualize and interact with the information, its correct operation will avoid distractions.

The contribution of this work refers to the definition of mobile learning in the teaching of mathematics considering its characteristics, the similarity with ubiquitous learning in relation to the creation of various contexts, and the identification of components for the relevant design of a learning environment. learning. In addition, the demand for theoretical, pedagogical and digital skills of teachers presents a challenge in formal education. These results could be of interest to future research on the relationships between technology and the various epistemological and pedagogical systems in the teaching of mathematical knowledge, so this work provides elements that could guide new research and applications, both in educational institutions and in schools. organizations and society.

\section{References}

Alsina, À., \& Domingo, M. (2010). Idoneidad didáctica de un protocolo sociocultural de enseñanza y aprendizaje de las matemáticas. Revista Latinoamericana de Investigacion En Matematica Educativa, 13(1), 7-32.

Aragón, E., Castro, C., Gómez, B., \& González, R. (2009). Objetos de aprendizaje como recursos didácticos para la enseñanza de matemáticas. Apertura: Revista de Innovación Educativa, 1(1), 100-111.

Bano, M., Zowghi, D., Kearney, M., Schuck, S., \& Aubusson, P. (2018). Mobile learning for science and mathematics school education: A systematic review of empirical evidence. Computers \& Education, 121, 30-58. https://doi.org/https://doi.org/10.1016/j.comped u.2018.02.006

Borba, M. C., Askar, P., Engelbrecht, J., Gadanidis, G., Llinares, S., \& Aguilar, M. S. (2016). Blended learning, e-learning and mobile learning in mathematics education. ZDM Mathematics Education, 48(5), 589-610. https://doi.org/10.1007/s11858-016-0798-4

Bray, A., \& Tangney, B. (2015). Enhancing student engagement through the affordances of mobile technology: a 21 st century learning perspective on realistic mathematics education. Mathematics Education Research Journal, 28(1), 173-197. https://doi.org/10.1007/s13394015-0158-7

Camacho Ríos, A., Caldera Franco, I. M., \& Valenzuela González, V. (2019). Fidelidad en el uso de app para la resolución de ecuaciones diferenciales. Apertura, 11(1), 74-89. https://doi.org/10.32870/Ap.v11n1.1463

Çetinkaya, L. (2019). The effects of problem based mathematics teaching through mobile applications on success. Egitim ve Bilim, 44(197), 65-84. https://doi.org/10.15390/EB.2019.8119

Chevallard, Y. (1992). Concepts fondamentaux de la didactique: perspectives apportées par une approache anthropologique. Recherches En Didactique Des Mathématiques, 12(1), 73-112. 
Crompton, H. (2013). Mobile learning: New approach, new theory. In Handbook of mobile learning (pp. 47-57). New York: Routledge.

D’Amore, B., Radford, L., \& Bagni, G. T. (2006). Ostacoli epistemologici e prospettiva socio-culturale. L'insegnamento Della Matematica e Delle Scienze Integrate, 29B(1), 11-40.

Duval, R. (2006). A Cognitive Analysis of Problems of Comprehension in a Learning of Mathematics. Educational Studies in Mathematics, 61(1), 106-131.

Fessakis, G., Karta, P., \& Kozas, K. (2018). Designing Math Trails for Enhanced by Mobile Learning Realistic Mathematics Education in Primary Education. International Journal of Engineering Pedagogy, 8(2), 49-63. https://doi.org/10.3991/ijep.v8i2.8131

Godino. (2013). Indicadores de la idoneidad didáctica de procesos de enseñanza y aprendizaje de las matemáticas. Cuadernos de Investigación y Formación En Educación Matemática, 8(11), 111-132.

Godino, J. (2003). Teoría de las funciones semióticas. Un enfoque ontológico-semiótico de la cognición e instrucción matemática. Granada.

Handal, B., Campbell, C., Cavanagh, M., \& Petocz, P. (2016). Characterising the perceived value of mathematics educational apps in preservice teachers. Mathematics Education Research Journal, 28(1), 199-221. https://doi.org/10.1007/s13394-015-0160-0

Hernández-Mosqueda, J., Tobón-Tobón, S., \& Vázquez-Antonio, J. (2014). Estudio conceptual de la docencia socioformativa. Ra Ximhai, 10(5), 89-101.

Joo Nagata, J., García-Bermejo Giner, J., \& Martínez Abad, F. (2017). Augmented reality in pedestrian navigation applied in a context of mobile learning: Resources for enhanced comprehension of science, technology, engineering and mathematics. International Journal of Engineering Education, 33(2), 768780.
Joung-Souk, S. (2009). U-Learning model design based on ubiquitous environment. International Journal of Advanced Science and Technology, 13, 77-88.

Juhan, J., \& Halkias, D. (2017). Middle school mathematics teachers' experiences with student learning using the hands-on equations iPad application: a narrative inquiry. International Journal of Technology Enhanced Learning, 9(1), 51-69. https://doi.org/10.1504/IJTEL.2017.10004886

Liu, J., \& Zhang, Y. (2017). Implementation of Information-based Teaching System for Young College Teachers Based on iOS Platform. International Journal of Emerging Technologies in Learning, 12(8), 14-26. https://doi.org/10.3991/ijet.v12.i08.7135

Ludwig, M., \& Jesberg, J. (2015). Using mobile technology to provide outdoor modelling tasks The MathCityMap-Project. Procedia - Social and Behavioral Sciences, 191, 2776-2781. https://doi.org/10.1016/j.sbspro.2015.04.517

Nicolete, P., Bilessimo, S., Cristiano, A., Simão, J., \& da Silva, J. (2017). Technology integration actions in mathematics teaching in brazilian basic education: Stimulating STEM disciplines. RED Revista de Educación a Distancia, (52). https://doi.org/10.6018/red/52/7

Radford, L. (2004). Sensible things , essences, mathematical objects, and other ambiguities. $L a$ Matematica e La Sua Didattica, 1(1), 4-23.

Ramírez Martinell, A., Casillas Alvarado, M. Á., \& Aguirre González, I. R. (2018). Habilitación tecnológica de profesores universitarios y docentes en educación básica. Apertura: Revista de Innovación Educativa, 10(2), 124-139.

Roberts, S. J. (2014). ENGage: The use of space and pixel art for increasing primary school children's interest in science, technology, engineering and mathematics. Acta Astronautica, 93, 34-44. https://doi.org/10.1016/j.actaastro.2013.06.013 
Rodríguez, G., Spiegel, A., Salviolo, M., \& Peña, A. (2015). Math, english and netbooks at the university. Learning across contexts? Procedia - Social and Behavioral Sciences, 176, 714-721.

https://doi.org/10.1016/j.sbspro.2015.01.531

Salvat, B. G. (2018). La evolución del elearning: del aula virtual a la red. RIED. Revista Iberoamericana de Educación a Distancia, 21(2), 69-82. https://doi.org/10.5944/ried.21.2.20577

Schuck, S. (2016). Enhancing teacher education in primary mathematics with mobile technologies. Australian Journal of Teacher Education, $\quad 41(3)$, 126-139. https://doi.org/10.14221/ajte.2016v41n3.8

Skiada, R., Soroniati, E., Gardeli, A., \& Zissis, D. (2014). EasyLexia: A Mobile Application for Children with Learning Difficulties. Procedia Computer Science, 27, 218-228. https://doi.org/10.1016/j.procs.2014.02.025

Tobon, S. (2017). Essential axes of knowledge society and socioformation (Primera). https://doi.org/10.24944/isbn. 978-1-945721$19-9$

Zhao, X., Wan, X., \& Okamoto, T. (2010). Adaptive content delivery in ubiquitous learning environment. The 6th IEEE International Conference on Wireless, Mobile, and Ubiquitous Technologies in Education, 19-36. https://doi.org/10.1109/WMUTE.2010.10 